ARTICLE

Received 23 Apr 2013 | Accepted 31 Jul 2013 | Published 29 Aug 2013 DOl: 10.1038/ncomms3383

\title{
A nanostructured cathode architecture for low charge overpotential in lithium-oxygen batteries
}

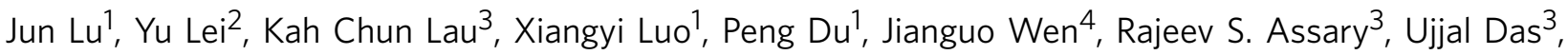 \\ Dean J. Miller ${ }^{4}$, Jeffrey W. Elam², Hassan M. Albishri ${ }^{5}$, D Abd El-Hady ${ }^{5}$, Yang-Kook Sun ${ }^{6}$, \\ Larry A. Curtiss ${ }^{3} \&$ Khalil Amine ${ }^{1,5}$
}

The lithium-oxygen battery, of much interest because of its very high-energy density, presents many challenges, one of which is a high-charge overpotential that results in large inefficiencies. Here we report a cathode architecture based on nanoscale components that results in a dramatic reduction in charge overpotential to $\sim 0.2 \mathrm{~V}$. The cathode utilizes atomic layer deposition of palladium nanoparticles on a carbon surface with an alumina coating for passivation of carbon defect sites. The low charge potential is enabled by the combination of palladium nanoparticles attached to the carbon cathode surface, a nanocrystalline form of lithium peroxide with grain boundaries, and the alumina coating preventing electrolyte decomposition on carbon. High-resolution transmission electron microscopy provides evidence for the nanocrystalline form of lithium peroxide. The new cathode material architecture provides the basis for future development of lithium-oxygen cathode materials that can be used to improve the efficiency and to extend cycle life.

\footnotetext{
${ }^{1}$ Chemical Science and Engineering Division, Argonne National Laboratory, Argonne, Illinois 60439, USA. ${ }^{2}$ Energy Systems Division, Argonne National Laboratory, Argonne, Illinois 60439, USA. ${ }^{3}$ Materials Science Division, Argonne National Laboratory, Argonne, Illinois 60439, USA. ${ }^{4}$ Electron Microscopy Center, Argonne National Laboratory, Argonne, Illinois 60439, USA. ${ }^{5}$ Department of Chemistry, Faculty of Science, King Abdulaziz University, 80203 Jeddah, Saudi Arabia. ${ }^{6}$ Department of Energy Engineering, Hanyang University, Seoul 133-791, South Korea. Correspondence and requests for materials should be addressed to Y.-K.S. (email: yksun@hanyang.ac.kr) or to L.A.C. (email: curtiss@anl.gov) or to K.A. (email: amine@anl.gov).
} 
T he Li- $\mathrm{O}_{2}$ battery is currently the subject of much scientific investigation because of its potential for very high-energy density exceeding that of any other existing energy storage systems $^{1,2}$. In the $\mathrm{Li}^{-} \mathrm{O}_{2}$ battery, a porous oxygen cathode is used to store the solid products generated from the reaction of $\mathrm{Li}$ cations with $\mathrm{O}_{2}$ during discharge. The cathode may contain a catalyst in some form to promote the discharge reaction. It has been found that a variety of factors dictate the nature of electrochemical reactions in Li-air cells including the nature of the catalyst, the catalyst distribution on the porous cathode, the pore volume of the cathode and the type of organic electrolyte used $^{3-10}$.

One of the major challenges for the development of $\mathrm{Li}-\mathrm{O}_{2}$ batteries is to lower the high overpotential during charge. A large overpotential on charge, even at very low current densities, can result in a very low round-trip efficiency $(<60 \%)$, low power capability and poor cycle life. Various electrocatalysts including carbons, metals and metal oxides have been examined as the cathode catalysts in the $\mathrm{Li}-\mathrm{O}_{2}$ cells to lower the charge overpotential. Some of the early work on $\mathrm{Li}^{-} \mathrm{O}_{2}$ batteries was based on carbonate electrolytes including catalysts such as $\alpha$ $\mathrm{MnO}_{2}, \mathrm{Co}_{3} \mathrm{O}_{4}, \mathrm{Mn}_{3} \mathrm{O}_{4}$ and $\mathrm{PtAu}^{11-15}$. However, carbonate electrolytes were found to decompose in $\mathrm{Li}_{-} \mathrm{O}_{2}$ batteries ${ }^{1,16,17}$ and consequently researchers turned to ether-based electrolytes, which have greater stability $8,11,18$. In a dimethoxyethane-based electrolyte, McCloskey et al. ${ }^{19}$ investigated the electrocatalytic role of $\mathrm{Au}, \mathrm{Pt}$ and $\mathrm{MnO}_{2}$ nanoparticles and found that none of these nanoparticles performs better than just a carbon surface. They also found that the charge potential at the beginning of the charge cycle is low $(\sim 3.4 \mathrm{~V})$ but rises to above $4 \mathrm{~V}$ during the first cycle. Nazar et al. ${ }^{20}$ investigated the use of small cobalt oxide nanoparticles and obtained a decrease in the charge potential to $\sim 3.8 \mathrm{~V}$ from $\sim 4.2 \mathrm{~V}$, which they attributed to mass transport effects rather than conventional electrocatalytic effects of the particles.

There may be a number of other contributing factors for the large charge overpotentials other than the lack of an effective electrocatalyst. Poor electronic conductivity of $\mathrm{Li}_{2} \mathrm{O}_{2}$ discharge product may limit the charge process, which depends on electron transport to the $\mathrm{Li}_{2} \mathrm{O}_{2} /$ electrolyte interface ${ }^{21-23}$. Contaminants in the $\mathrm{Li}_{2} \mathrm{O}_{2}$ discharge product from electrolyte decomposition such as $\mathrm{Li}_{2} \mathrm{CO}_{3}$ may also cause a higher charge potential. McCloskey et al. ${ }^{24}$ showed that decomposition may result from reaction of the electrolyte with defects on the carbon surface, whereas Bruce et al. ${ }^{25}$ showed that oxidation of the carbon surface can occur at voltages as low as $3.5 \mathrm{~V}$ during charge in the presence of $\mathrm{Li}_{2} \mathrm{O}_{2}$. Interestingly, Norskov et al. ${ }^{26}$ have shown that the theoretical overcharge potential for a $\mathrm{Li}_{2} \mathrm{O}_{2}$ film is only $0.2 \mathrm{~V}$ for some surfaces, assuming no limitations in charge transport through $\mathrm{Li}_{2} \mathrm{O}_{2}$ to the $\mathrm{Li}_{2} \mathrm{O}_{2}$-electrolyte interface. Therefore, it may be possible to significantly lower the charge potential if solutions to the above problems can be discovered.

In this paper, we describe a conceptually new approach as illustrated in Fig. 1 based on a new cathode architecture for the $\mathrm{Li}-\mathrm{O}_{2}$ cells that shows promising results for solving the charge overpotential problem. The cathode architecture addresses the electrolyte decomposition problem with a porous carbon passivated by a protective $\mathrm{Al}_{2} \mathrm{O}_{3}$ coating applied by atomic layer deposition (ALD). Very small Pd nanoparticles attached to the surface by ALD act as effective electrocatalysts and seem to promote formation of a nanocrystalline form of $\mathrm{Li}_{2} \mathrm{O}_{2}$ that provides good electronic transport. The resulting low charge overpotential is about $0.2 \mathrm{~V}$. The lithium peroxide is characterized by X-ray diffraction (XRD), scanning electron microscopy (SEM) as well as high-resolution transmission electron microscopy (HRTEM) techniques. Computational modelling is used to

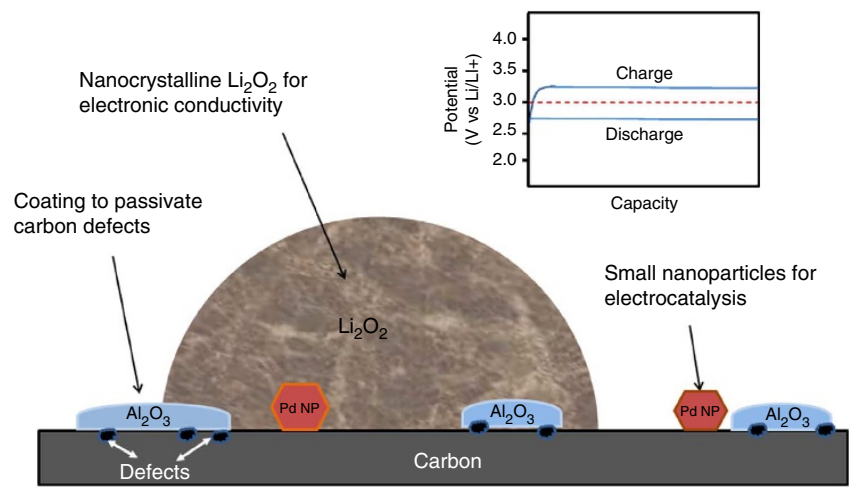

Figure 1 | Schematic of the nanostructured cathode architecture. This figure shows the $\mathrm{Al}_{2} \mathrm{O}_{3}$ coating, the palladium nanoparticles and the nanocrystalline lithium peroxide, all of which contribute to lowering the overpotential. The inset shows a hypothetical charge/discharge voltage profile versus capacity.

provide an insight into the role of the $\mathrm{Al}_{2} \mathrm{O}_{3}$ protective coating and the Pd nanoparticles for preventing electrolyte decomposition and catalysing the lithium peroxide decomposition, respectively.

\section{Results}

Synthesis and characterization of the cathode architecture. The synthesis of the new cathode architecture was done using ALD, a technique for preparing thin films that employs self-limiting chemical reactions between gaseous precursors and a solid surface allowing atomic scale control over the film thickness and composition ${ }^{27}$. One of the distinguishing attributes of ALD is the capability to deposit coatings on surfaces with complex topographies and to infiltrate mesoporous materials, important for the $\mathrm{Al}_{2} \mathrm{O}_{3}$ coatings used for the cathode in this study ${ }^{28-30}$. The ALD technique can also be used to synthesize supported noble metal catalysts, such as Pd used in this work, in the size range from subnanometres to nanometres ${ }^{31-34}$.

Super P Li (SPL) conductive carbon black with a typical particle size of $40 \mathrm{~nm}$ and a surface area of $62 \mathrm{~m}^{2} \mathrm{~g}^{-1}$ was used as the catalyst support material. We first coated the carbon surface with three cycles of $\mathrm{Al}_{2} \mathrm{O}_{3}$ by ALD, which deposits on the carbon defect sites 35,36 and thus acts to passivate the defects on the carbon surface (Supplementary Note 1). Then, three cycles of ALD were used to load palladium nanoparticles on the surface to serve as electrocatalytic sites.

Representative HRTEM images of the uncoated carbon, $\mathrm{Al}_{2} \mathrm{O}_{3}$ coated carbon and $\mathrm{Al}_{2} \mathrm{O}_{3}$-coated carbon with $\mathrm{Pd}$ nanoparticles are shown in Fig. 2. The pristine carbon surface is shown in Fig. 2a. In Fig. 2b, it is shown that the carbon surface is only partially covered by the $\mathrm{Al}_{2} \mathrm{O}_{3}$ after the three cycles of ALD. The partially covered carbon surface is characterized by islands of $\mathrm{Al}_{2} \mathrm{O}_{3}$ that deposit on defect sites leaving some carbon surface exposed. The carbon defect sites could be, for example, carbonyl, alcohol and ether groups, which have been found to be reactive towards the tetramethylaluminium precursor in coating of polyethers ${ }^{37}$. The $\mathrm{Al}_{2} \mathrm{O}_{3}$ islands are $\sim 0.5 \mathrm{~nm}$ thick. Figure $2 \mathrm{c}, \mathrm{d}$ shows the Pd nanoparticle size, size distribution and interparticle distance on the carbon support. Figure $2 \mathrm{e}$,f shows that the Pd nanoparticles are attached to the carbon support as indicated by the wavy fringes characteristic of the carbon sheets. Moreover, the amorphous $\mathrm{Al}_{2} \mathrm{O}_{3}$ islands are attached to regions of the carbon support surface near the $\mathrm{Pd}$. The size of the Pd nanoparticles from the HRTEM images is in the range of $2-6 \mathrm{~nm}$, although smaller Pd clusters cannot necessarily be ruled out. 

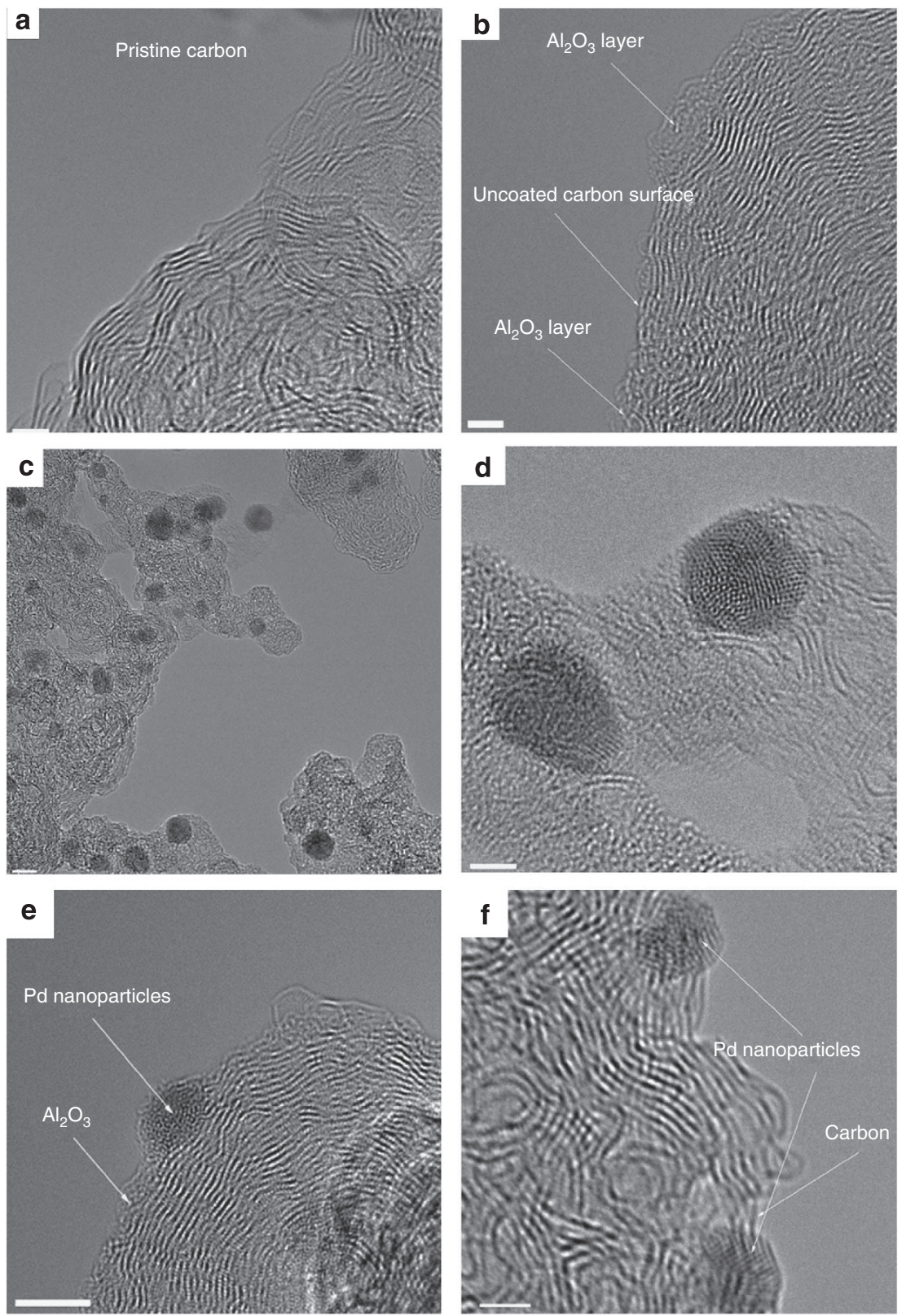

Figure 2 | HRTEM of the cathode structure. (a) Pristine super $\mathrm{P}$ carbon (scale bar, $2 \mathrm{~nm}$ ); (b) carbon surface coated with three $A L D$ cycles of $\mathrm{Al}_{2} \mathrm{O}_{3}$ $\left(\mathrm{Al}_{2} \mathrm{O}_{3} / \mathrm{C}\right)$, (scale bar, $\left.2 \mathrm{~nm}\right) ;(\mathbf{c}-\mathbf{f})$ carbon + three $\mathrm{ALD}$ cycles $\mathrm{Al}_{2} \mathrm{O}_{3}+\mathrm{Pd}$ nanoparticles from three ALD cycles $\left(\mathrm{Pd} / \mathrm{C}\left[\mathrm{Al} \mathrm{I}_{2} \mathrm{O}_{3}\right]\right)$, (scale bars in $(\mathbf{c}-\mathbf{f})$, $5 \mathrm{~nm}, 2 \mathrm{~nm}, 4 \mathrm{~nm}$ and $2 \mathrm{~nm}$, respectively).

The Pd nanoparticles and carbon surface were examined further using various spectroscopic techniques. X-ray adsorption spectroscopy (XAS) of the cathode in air at room temperature is shown in Fig. 3 along with the reference spectra recorded for Pd foil and PdO standard. X-ray absorption near-edge spectroscopy (XANES) are also given in Fig. 3 The XAS and XANES spectra indicate that the Pd nanoparticles from the three cycles of ALD are similar to bulk Pd, although the XANES spectra also shows that they are oxidized to some extent. The oxide fraction of the Pd nanoparticles is estimated to be about $20 \%$, indicating that the Pd nanoparticle surface is largely oxidized. X-ray photoelectron spectroscopy (XPS) was used to investigate the nature of the $\mathrm{Al}_{2} \mathrm{O}_{3}$-coated carbon surface. The XPS spectra shown in Fig. 3 indicate that the $\mathrm{Al}_{2} \mathrm{O}_{3}$, coating by ALD, decreases the amount of defects on the carbon as evidenced by the disappearance of $\mathrm{C}=\mathrm{O}$ (Fig. 3c,d) and O-H (Fig. 3d) peaks, although C-O bonds remain.
Performance of the cathode architecture. The performance of this new cathode architecture as well as two architectures without $\mathrm{Pd}$ nanoparticles was then evaluated using a Swagelok-type cell ${ }^{16}$ composed of a lithium metal anode, electrolyte $\left(1 \mathrm{M} \mathrm{LiCF}_{3} \mathrm{SO}_{3}\right.$ in tetraethylene glycol dimethyl ether (TEGDME) impregnated into a glass fibre separator) and a porous cathode (13 $\mathrm{mm}$ diameter). Figure 4 shows voltage profiles recorded during the first discharge/ charge cycle obtained when a cell was subject to discharge first for the three cathode architectures: super $\mathrm{P}$ carbon only $(\mathrm{C})$, super $\mathrm{P}$ coated with $\mathrm{Al}_{2} \mathrm{O}_{3}\left(\mathrm{Al}_{2} \mathrm{O}_{3} / \mathrm{C}\right)$, and super $\mathrm{P}$ coated with $\mathrm{Al}_{2} \mathrm{O}_{3}$ and $\mathrm{Pd}$ nanoparticles $\left(\mathrm{Pd} / \mathrm{C}\left[\mathrm{Al}_{2} \mathrm{O}_{3}\right]\right)$. The cells were discharged to a capacity of $1,000 \mathrm{mAh} \mathrm{g}^{-1}$ and then charged. The voltage profiles show that the charge potential is $\sim 4.2$ and $\sim 4.4 \mathrm{~V}$ for the $\mathrm{C}$ and $\mathrm{Al}_{2} \mathrm{O}_{3}-\mathrm{C}$ cathodes, respectively, and that the potential is significantly reduced to about $3.2 \mathrm{~V}$ (compared with the theoretical $3.0 \mathrm{~V}^{25}$ ) for the entire charge on the $\mathrm{Pd} / \mathrm{Al}_{2} \mathrm{O}_{3} / \mathrm{C}$ cathode. 

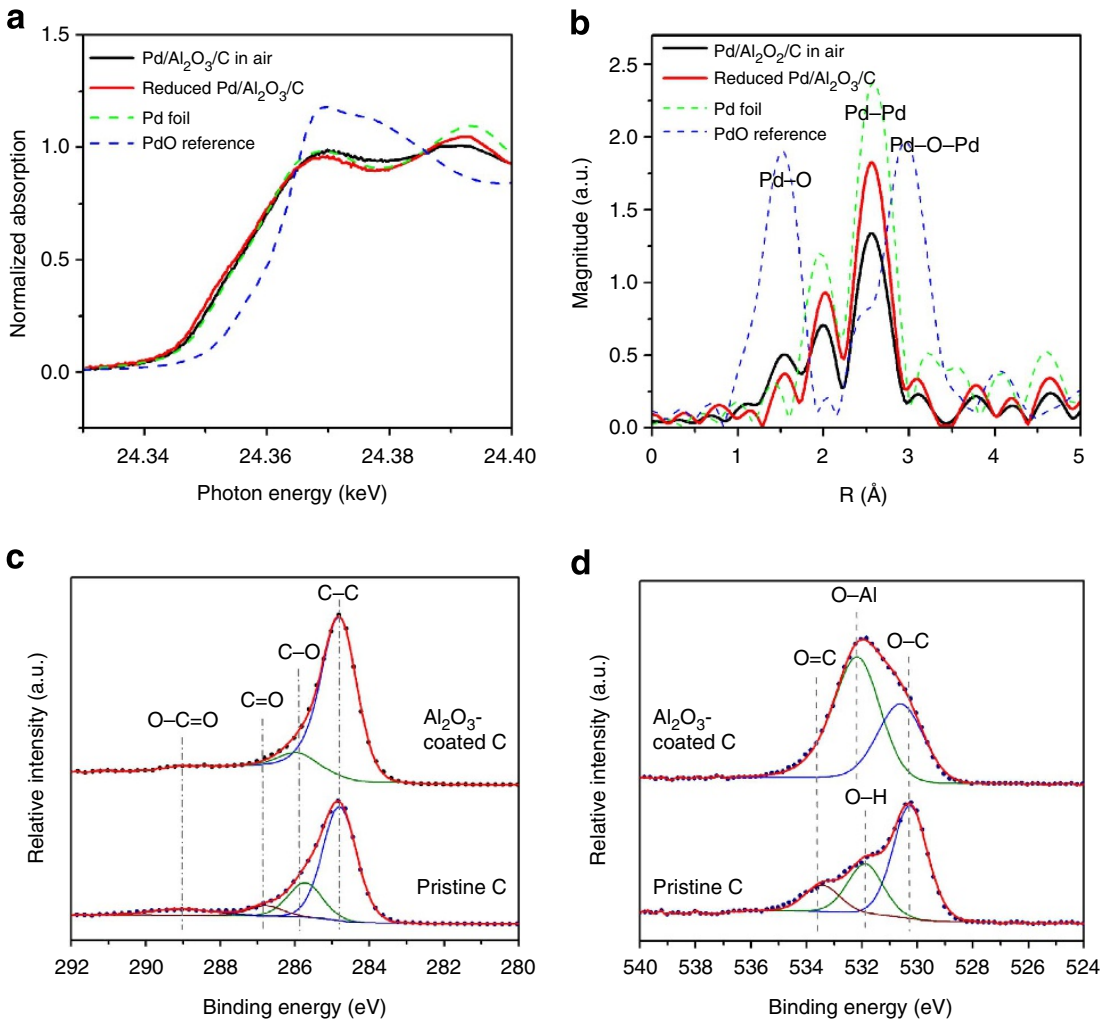

Figure 3 | XANES and XPS spectra. (a) XANES spectra for as-prepared 3c-Pd/3c- $\mathrm{Al}_{2} \mathrm{O}_{3} /$ carbon in air and reduced $3 c-P d / 3 c-A l_{2} \mathrm{O}_{3} / \mathrm{carbon}$ along with spectra for metallic Pd foil reference and Pd oxide reference. (b) Fourier transform of X-ray absorption spectra $(k 2: \Delta k=2.8-11 \AA-1)$ for as-prepared $3 \mathrm{c}-\mathrm{Pd} / 3 \mathrm{c}-\mathrm{Al}_{2} \mathrm{O}_{3} / \mathrm{carbon}$ in air and reduced $3 \mathrm{c}-\mathrm{Pd} / 3 \mathrm{c}-\mathrm{Al}_{2} \mathrm{O}_{3} /$ carbon along with spectra for metallic Pd foil reference and $\mathrm{Pd}$ oxide reference. (c) $\mathrm{C}$ s XPS spectra of uncoated and $3 \mathrm{c}-\mathrm{Al}_{2} \mathrm{O}_{3}$-coated carbon, (d) O1s XPS spectra of uncoated and $3 \mathrm{c}-\mathrm{Al}_{2} \mathrm{O}_{3}$-coated carbon. $3 \mathrm{c}$ represents three cycles of $\mathrm{ALD}$.

The observed low charge potential can be maintained for over 10 cycles at $500 \mathrm{mAhg}^{-1}$ capacity on the $\mathrm{Pd} / \mathrm{C}\left[\mathrm{Al}_{2} \mathrm{O}_{3}\right]$ cathode as shown in Fig. $4 \mathrm{~b}$. After 10 cycles, the cell starts to fail with deeper discharge required and larger charge overpotentials with complete failure occurring at about 15 cycles (Supplementary Fig. S1). One possible cause of the failure is the degradation of the $\mathrm{Li}$ anode as shown by the corrosion of the anode at termination (Supplementary Fig. S2). In previous work ${ }^{38}$, XRD and Fourier transform infrared spectroscopic measurements have been used to analyse such corroded lithium anodes and was shown to be because of an oxygen crossover effect that results in the formation of $\mathrm{LiOH}$ and $\mathrm{Li}_{2} \mathrm{CO}_{3}$. Another possible cause of failure after 10 cycles is poisoning of the $\mathrm{Pd}$ catalyst by contaminants or passivation. A build-up of contaminants such as $\mathrm{Li}_{2} \mathrm{CO}_{3}$ could be the result of gradual decomposition of the TEGDME electrolyte such as by reaction with the $\mathrm{Li}_{2} \mathrm{O}_{2}$ surface as found experimentally ${ }^{24}$. We also note that when this cell is run to full discharge $\left(2,750 \mathrm{mAh} \mathrm{g}^{-1}\right)$, it has a much larger charge overpotential (Supplementary Fig. S3).

Characterization of the discharge product. The discharge product was examined using SEM imaging and identified as lithium peroxide through the use of XRD. The SEM images in Fig. 4d,f show the carbon cathode after discharge and charge at the 1st and 10 th cycles. The discharge product has a toroid-shaped morphology that has been found by others in $\mathrm{Li}^{-} \mathrm{O}_{2}$ cells ${ }^{18,20,39}$. The toroids are absent from the surface of the cathode after charge as evidenced by the SEM images of Fig. 4d,f.

The lithium peroxide discharge product was further probed by HRTEM imaging and results are shown in Fig. 5. A low- magnification TEM image of a toroid is shown in Fig. 5a along with an electron diffraction pattern in Fig. $5 \mathrm{~b}$ consistent with $\mathrm{Li}_{2} \mathrm{O}_{2}$. The electron diffraction pattern indicates that the toroids are nanocrystalline, which means that it consists of grains and grain boundaries. Evidence for the nanosized grains is shown in Fig. 5c. The HRTEM images in Fig. 5a also show evidence for the Pd nanoparticles in the carbon near the toroids. The XRD patterns of the discharged cathode shown in Fig. 5d demonstrate the presence of $\mathrm{Li}_{2} \mathrm{O}_{2}$, with no evidence of other crystalline materials such as $\mathrm{Li}_{2} \mathrm{CO}_{3}$ or $\mathrm{LiOH}$ (although some trace amounts of amorphous $\mathrm{Li}_{2} \mathrm{CO}_{3}$ or $\mathrm{LiOH}$ may accumulate with cycling) and the disappearance of $\mathrm{Li}_{2} \mathrm{O}_{2}$ with charge.

\section{Discussion}

As far as we are aware, a charge overpotential as small as $0.2 \mathrm{~V}$ (Fig. 4) has not been previously reported for a non-aqueous $\mathrm{Li}-\mathrm{O}_{2}$ cell. The low charge potential found here is due to a synergy of various aspects of the $\mathrm{Pd} / \mathrm{C}\left[\mathrm{Al}_{2} \mathrm{O}_{3}\right]$ cathode architecture. The effect of the $\mathrm{Pd}$ nanoparticles attached to the carbon surface is clearly evident from the reduction in the charge potential by about $1.2 \mathrm{~V}$ from the charge potential $(\sim 4.4 \mathrm{~V})$ for the $\mathrm{Al}_{2} \mathrm{O}_{3}-\mathrm{C}$ cathode without nanoparticles in Fig. 4. Density functional calculations in Fig. 6a show that a partially oxidized Pd nanoparticle $(\sim 1 \mathrm{~nm})$ forms bonds to a defect-free graphene surface, which provides a good interface for electron transfer. This has also been noted as a key property for the use of Pd nanoparticles in sensors based on Pd nanoparticle/carbon nanotube composites ${ }^{40}$. In addition, the density of states of the partially oxidized Pd nanoparticle bonded to a carbon surface in Fig. $6 \mathrm{~b}$ indicates that the $\mathrm{Pd}-\mathrm{C}$ interface should be good for 
a
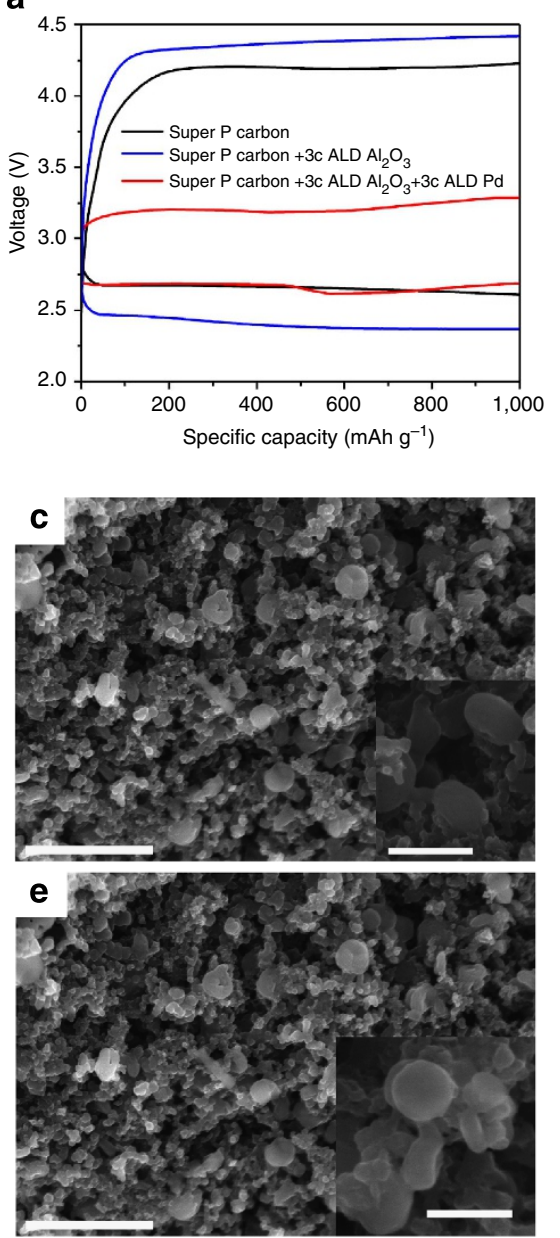

b
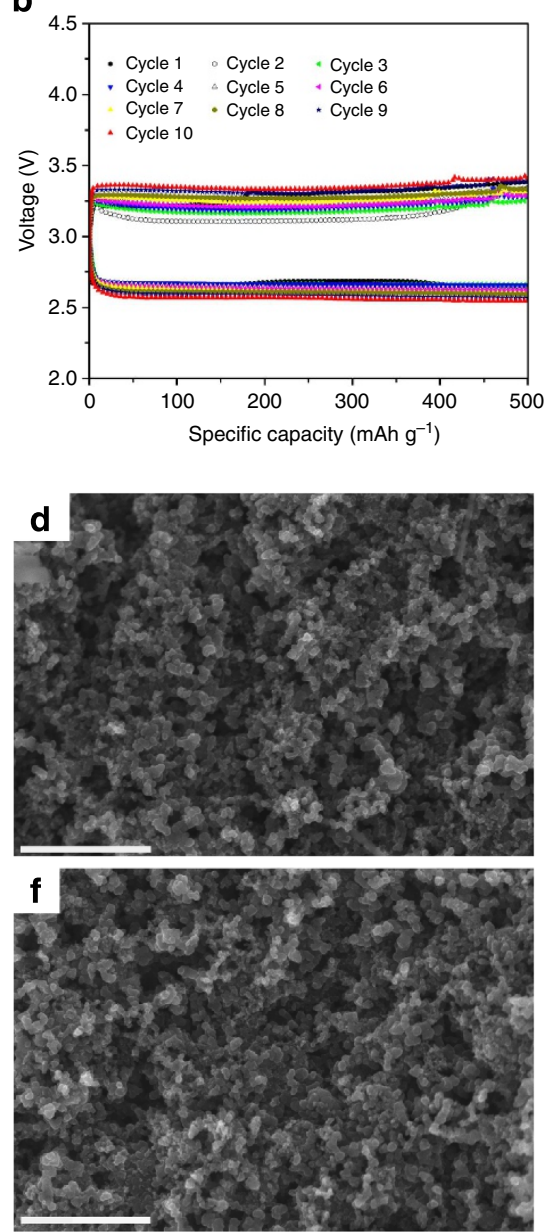

Figure 4 | Voltage profiles and SEM images. (a) Voltage profile during discharge-charge of cells (to 1,000 $\mathrm{mAh}^{-1}$ ) based on super $\mathrm{P}$ carbon; super $\mathrm{P}$ carbon coated with $\mathrm{Al}_{2} \mathrm{O}_{3}$; and $\mathrm{Al}_{2} \mathrm{O}_{3}$-coated super $\mathrm{P}$ carbon further coated with $\mathrm{Pd}$ nanoparticles. The electrolyte used is TEGDME-LiCF $\mathrm{SO}_{3}$; (b) voltage profile during discharge-charge of cells (to $5,00 \mathrm{mAhg}{ }^{-1}$ ) based on $\mathrm{Al}_{2} \mathrm{O}_{3}$-coated super $\mathrm{P}$ carbon further coated with Pd nanoparticles. The electrolyte used is TEGDME-LiCF $\mathrm{SO}_{3}$. (c) SEM of 1st cycle after discharge to $500 \mathrm{mAh} \mathrm{g}^{-1}$ ( $\mathrm{scale}^{\mathrm{c}}$ bar, $1 \mu \mathrm{m}$; scale bar of inset image, $400 \mathrm{~nm}$ ); (d) SEM of 1st cycle after charge, (scale bar, $1 \mu \mathrm{m}$ ); (e) SEM of 10th cycle after discharge to $500 \mathrm{mAh}^{-1}$, (scale bar, $1 \mu \mathrm{m}$; scale bar of the inset image, $300 \mathrm{~nm}$ ); (f) SEM of 10 th cycle after charge, (scale bar, $1 \mu \mathrm{m}$ ).

electronic transport across the interface needed for electrocatalysis. The electrocatalytic properties of the $\mathrm{Pd}$ nanoparticles are apparent from the change in the discharge potential from $\sim 2.7 \mathrm{~V}$ with $\mathrm{Pd}$ on the cathode $\left(\mathrm{Pd} / \mathrm{C}\left[\mathrm{Al}_{2} \mathrm{O}_{3}\right]\right)$ to $\sim 2.5 \mathrm{~V}$ (Fig. $\left.4 \mathrm{a}\right)$ when there are no $\mathrm{Pd}$ nanoparticles on the cathode $\left(\mathrm{Al}_{2} \mathrm{O}_{3} / \mathrm{C}\right)$. In addition, the defect sites on the carbon-only cathode also have similar electrocatalytic properties on discharge, as the discharge potential is also $\sim 2.7 \mathrm{~V}$.

In addition to the electrocatalytic effect of the Pd nanoparticles, the electronic properties of the lithium peroxide discharge product resulting from the presence of the $\mathrm{Pd}$ nanoparticles are believed to have an important role in lowering the charge overpotential. The charge overpotential will depend on the electronic transport in the lithium peroxide discharge product $^{21,22,26}$. As noted previously, with no limitations on electronic transport, the charge overpotential should be small. The nanocrystalline nature of the lithium peroxide discharge product for the $\mathrm{Pd}-\mathrm{Al}_{2} \mathrm{O}_{3}-\mathrm{C}$ cathode (Fig. 5) with small 2-10 nm grains and grain boundaries can provide a mechanism for good electronic transport for charging. This discharge product morphology may appear because the $\mathrm{Pd}$ nanoparticles provide nucleation sites for a form of lithium oxide growth species that assemble into the nanocrystalline $\mathrm{Li}_{2} \mathrm{O}_{2}$ discharge product with these characteristics. We have carried out density functional calculations on amorphous lithium peroxide that is likely present in the grain boundaries, and the calculations show that amorphous $\mathrm{Li}_{2} \mathrm{O}_{2}$ may have a metal-like density of states. (Supplementary Fig. S4; the other two cathode materials ( $\mathrm{C}$ and $\left.\mathrm{Al}_{2} \mathrm{O}_{3} / \mathrm{C}\right)$ have much higher charge potentials $(4.2-4.4 \mathrm{~V}$ in Fig. 4), which may be because of the different morphologies of the discharge products from these cathodes as shown by their s.e.m. images (Supplementary Fig. S5) and also the lack of the Pd nanoparticle electrocatalyst. All the cathodes were investigated with the same TEGDME- $\mathrm{LiCF}_{3} \mathrm{SO}_{3}$ electrolyte. It is also possible that some electrolytes have different $\mathrm{Li}_{2} \mathrm{O}_{2}$ morphologies, which may avoid the decomposition problem. This will be the subject for a future systematic study.

Finally, the $\mathrm{Al}_{2} \mathrm{O}_{3}$ coating on the new cathode architecture also has a role in the lower charge potential found for the $\mathrm{Pd} / \mathrm{C}\left[\mathrm{Al}_{2} \mathrm{O}_{3}\right]$ $\mathrm{Li}-\mathrm{O}_{2}$ cell. This coating on the new cathode will prevent decomposition of the TEGDME electrolyte by blocking reaction of the TEGDME solvent molecule with the defect sites on the carbon surface. Density functional calculations were carried out on several possible types of defect sites on a graphitized surface (Supplementary Fig. S6). The interaction of TEGDME with one type of carbon defect sites is shown in Fig. $6 \mathrm{c}$ and shows that it is 

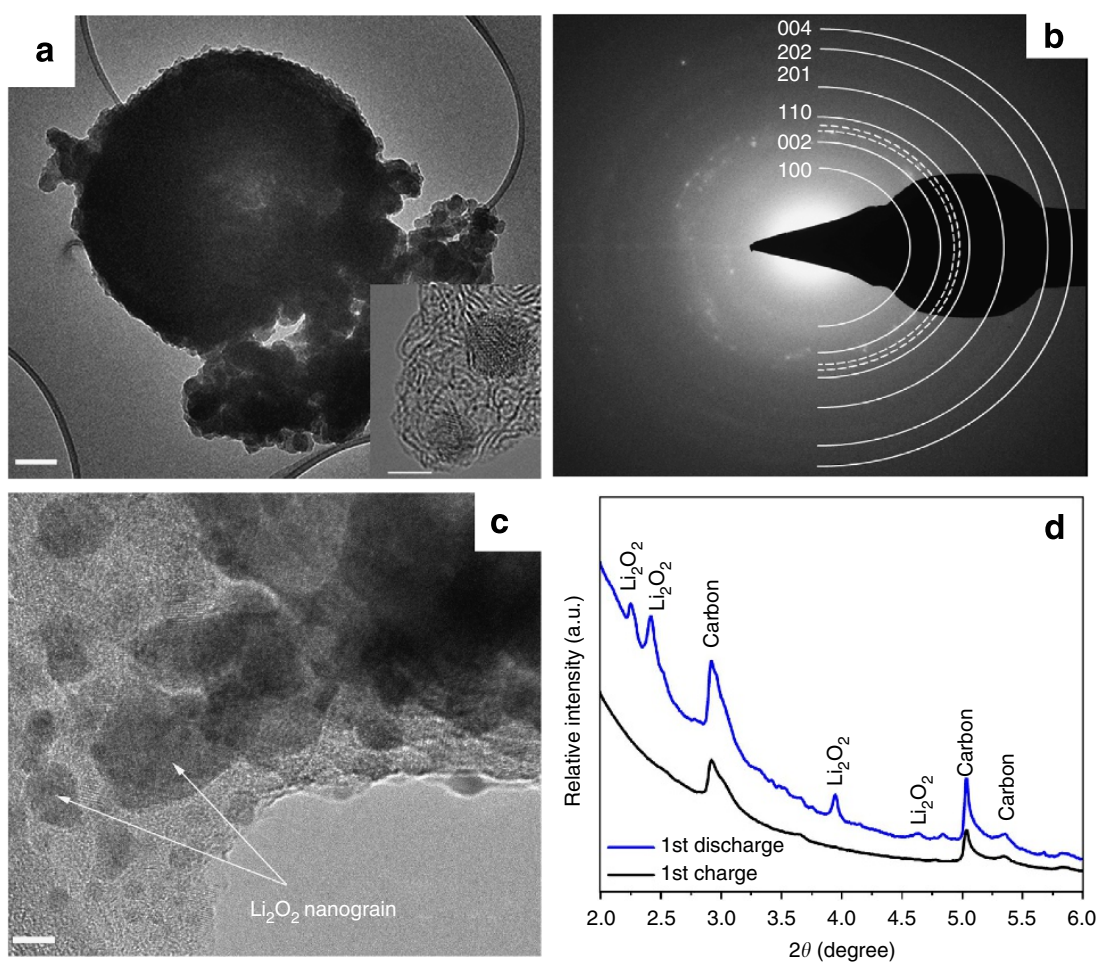

Figure 5 | TEM images and XRD patterns. (a) TEM image of $\mathrm{Li}_{2} \mathrm{O}_{2}$ toroid from discharge to $2.5 \mathrm{~V}$ (scale bar, $100 \mathrm{~nm}$ ), inset figure is a HRTEM image of carbon support showing the presence of Pd nanoparticles (scale bar, $3 \mathrm{~nm}$ ); (b) electron diffraction pattern of the $\mathrm{Li}_{2} \mathrm{O}_{2}$ toroid; (c) HRTEM image of $\mathrm{Li}_{2} \mathrm{O}_{2}$ toroid (scale bar, $4 \mathrm{~nm}$ ); and (d) XRD pattern of 1st discharge product showing the presence of $\mathrm{Li}_{2} \mathrm{O}_{2}$ and the 1st cycle charge showing the absence of $\mathrm{Li}_{2} \mathrm{O}_{2}$ on the $\mathrm{Pd} / \mathrm{C}\left[\mathrm{Al}_{2} \mathrm{O}_{3}\right]$ cathode.

exothermically very favourable to decompose by breaking a C-O bond at the site. Similar results were found at other defect sites (Supplementary Fig. S7). In contrast, the density functional calculations in Fig. $6 \mathrm{~d}$ show that an $\mathrm{Al}_{2} \mathrm{O}_{3}$ surface is very unreactive towards the TEGDME molecule and will not result in decomposition (Supplementary Fig. S8). Electrolyte decomposition on carbon defect sites will result in the deposition of contaminants such as carbonates on the lithium peroxide discharge product or on the carbon surface and likely increase the charge potential ${ }^{24}$. In addition, a low charge potential of $<3.5 \mathrm{~V}$ as found for the $\mathrm{Pd}-\mathrm{Al}_{2} \mathrm{O}_{3}-\mathrm{C}$ will prevent side reactions involving the carbon surface and $\mathrm{Li}_{2} \mathrm{O}_{2}$ that may occur on charge ${ }^{24,25}$, although decomposition reactions ${ }^{24,41}$ on the $\mathrm{Li}_{2} \mathrm{O}_{2}$ surface may still occur. We also used a $\mathrm{Li}-\mathrm{O}_{2}$ cathode based on $\mathrm{Pd}$ nanoparticles (from the three cycles of ALD) on super $\mathrm{P}$ without the $\mathrm{Al}_{2} \mathrm{O}_{3}$ coating. The charge potential for this cell was about $4 \mathrm{~V}$ (Supplementary Fig. S9). This provides further evidence for the importance of a coating to passivate defect sites such as $\mathrm{Al}_{2} \mathrm{O}_{3}$ to attain the low charge overpotentials.

From the above information and the concepts in Fig. 1, we can speculate on the mechanisms for the discharge and charge processes for the $\mathrm{Pd} / \mathrm{Al}_{2} \mathrm{O}_{3} / \mathrm{C}$ cathode. If the discharge process involves electrocatalytic growth and nucleation of $\mathrm{Li}_{2} \mathrm{O}_{2}$ nanoparticles on $\mathrm{Pd}$ sites, then subsequent transport through the electrolyte and aggregation could result in the nanocrystalline $\mathrm{Li}_{2} \mathrm{O}_{2}$ morphology with small 2-10 nm grains that make up the toroids. The charge process involving decomposition of the toroids at a low charge overpotential would be facilitated by the small $\mathrm{Li}_{2} \mathrm{O}_{2}$ grains in the toroids, conduction through grain boundaries and electronic contact with the cathode surface.

In summary, a cathode architecture that utilizes nanoscale components has been shown to achieve a dramatic reduction in charge overpotential (to $\sim 0.2 \mathrm{eV}$ ). The cathode promotes growth of a nanocrystalline form of lithium peroxide with electronic transport properties that are needed to lower the charge potential. In addition, the protective $\mathrm{Al}_{2} \mathrm{O}_{3}$ coating on the cathode prevents electrolyte decomposition on carbon defect sites, which can also increase the charge potential. This new cathode architecture opens promising new avenues for $\mathrm{Li}-\mathrm{O}_{2}$ battery development through optimization of the metal nanoparticle and the carbon support, as well as incorporation of new protective coatings on cathodes.

\section{Methods}

Cathode preparation. SPL conductive carbon black with a typical particle size of $40 \mathrm{~nm}$ and a surface area of $62 \mathrm{~m}^{2} \mathrm{~g}^{-1}$ was used as the catalyst support material. ALD was performed in a continuous-flow stainless steel reactor described in detail elsewhere. About $100 \mathrm{mg}$ of the SPL carbon powder was carefully spread onto a stainless steel tray and a stainless steel mesh cover was clamped over the tray to contain the powder while still providing access to the ALD precursor vapours. The carbon powder was held in the reactor at $200^{\circ} \mathrm{C}$ under continuous flow of 300 s.c.c.m. ultra-high-purity nitrogen carrier gas at 1 torr pressure for $30 \mathrm{~min}$ to outgas and achieve thermal equilibrium. The $\mathrm{Al}_{2} \mathrm{O}_{3}$ ALD used alternating exposures to trimethylaluminium (Sigma-Aldrich, 97\%) and deionized water at $200^{\circ} \mathrm{C}$. Exposure/purge time $60-120-60-180 \mathrm{~s}$ was used. The three cycles of $\mathrm{Al}_{2} \mathrm{O}_{3}$ ALD on the carbon black powder were performed to cover the carbon defect sites. After the $\mathrm{Al}_{2} \mathrm{O}_{3}$ ALD cycles, the Pd ALD was then performed using alternating exposures to palladium hexafluoroacetylacetonate $\left(\mathrm{Pd}(\mathrm{hfac})_{2}\right.$, Aldrich, $\left.99.9 \%\right)$ and formalin (Sigma-Aldrich, $\mathrm{HCHO} 37 \mathrm{wt} \%$ in $\mathrm{H}_{2} \mathrm{O}$ ) at $200^{\circ} \mathrm{C}$. Timing sequence of a complete ALD cycle can be expressed as $t_{1}-t_{2}-t_{3}-t_{4}$, corresponding to the precursor exposure time, $\mathrm{N}_{2}$ purge time, co-reactant exposure time and $\mathrm{N}_{2}$ purge time, respectively. The timing sequence utilized for the Pd ALD was 100-300-100-300. Catalyst samples were prepared using three Pd ALD cycles on the three cycles of $\mathrm{ALD} \mathrm{AL}_{2} \mathrm{O}_{3}$-coated carbon powder.

Electrochemical methods. Electrochemical characterization was carried out using a Swagelok-type cell composed of a lithium metal anode, electrolyte $\left(1 \mathrm{M} \mathrm{LiCF}_{3} \mathrm{SO}_{3}\right.$ in TEGDME impregnated into a glass fibre separator) and a porous cathode ( $13 \mathrm{~mm}$ diameter). The cathode was formed by casting a mixture of the as-prepared $\mathrm{Pd} / \mathrm{SPL}$ carbon and binder in a molar ratio of 80:20. The cells were sealed except 
b
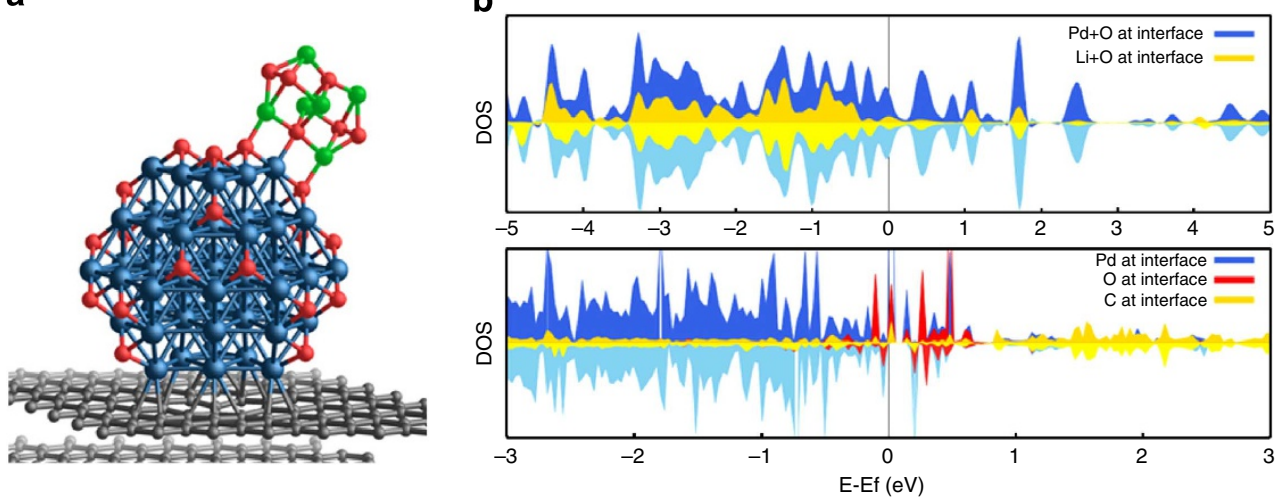

C

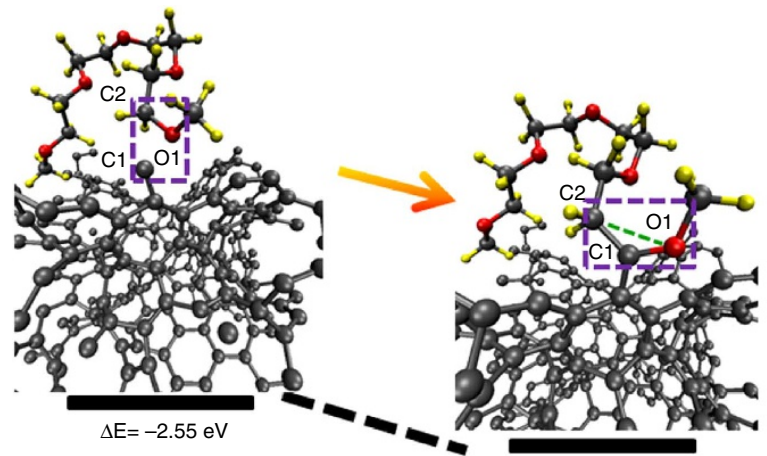

d

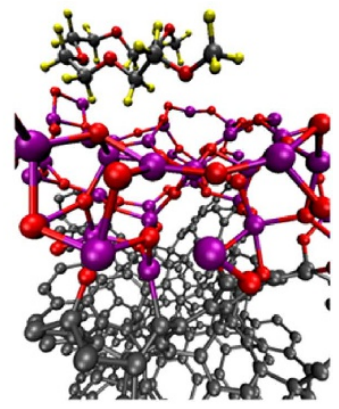

Figure 6 | Density functional calculations. (a) Density functional theory (DFT)-calculated structure of the $\mathrm{Li}_{2} \mathrm{O}_{2} / \mathrm{Pd}_{55} \mathrm{O}_{21} / \mathrm{C}$ interface, where $\mathrm{Pd}{ }_{55} \mathrm{O}_{21}$ represents a partially oxidized palladium nanoparticle. Colour code: palladium (blue), aluminium (purple), oxygen (red), lithium (green), hydrogen (yellow) and carbon (grey). Lithium peroxide $\left(\mathrm{Li}_{2} \mathrm{O}_{2}\right)$ is represented by a cluster containing three $\mathrm{Li}_{2} \mathrm{O}_{2}$ monomers. The carbon electrode $(\mathrm{C})$ is represented by two stacked graphene layers. The average $\mathrm{Pd}-\mathrm{C}$ bond length is $2.4 \AA$ and the average $\mathrm{Pd}-\mathrm{O}$ bond length with lithium peroxide is $2.0 \AA$. (b) Projected density of states at the $\mathrm{Li}_{2} \mathrm{O}_{2} / \mathrm{Pd}_{55} \mathrm{O}_{21}$ interface (top) and $\mathrm{Pd}_{55} \mathrm{O}_{21} / \mathrm{C}$ interface (bottom). In both cases, only the interface atoms that are in direct contact with each other have been considered. The up and down spin electron densities are represented by dark and light colours, respectively. (c) DFT calculations of a TEGDME solvent molecule binding on a carbon defect site on a bare graphitized carbon surface. The TEGDME molecule decomposes and forms new $\mathrm{C}-\mathrm{O}$ and $\mathrm{C}-\mathrm{H}$ bonds on these sites. (d) Weakly bound TEDGME molecule $\left(0.1 \mathrm{eV}\right.$ ) on an $\mathrm{Al}_{2} \mathrm{O}_{3}-\mathrm{coated}$ carbon surface.

for the $\mathrm{Al}$ grid window that exposed the porous cathode to 1 bar $\mathrm{O}_{2}$ pressure. The electrochemical measurements were carried out using a Biologic MacPile cycler. The discharge-charge performance was conducted in at a constant current of $100 \mathrm{mAg} \mathrm{g}^{-1}$, and the cell was maintained in 1 bar $\mathrm{O}_{2}$ atmosphere to avoid any negative effects of humidity and $\mathrm{CO}_{2}$. For comparison, a blank SPL carbon without any catalyst was also tested using the same cell configuration described above. We normalized the observed capacity by the weight of the carbon and catalyst for comparison in this study.

X-ray absorption spectroscopy. Pd K-edge $(23.564 \mathrm{keV}) \mathrm{XAS}$ was performed at the Materials Research Collaborative Access Team at the Advanced Photon Source, Argonne National Laboratory. The sample was loaded as a self-supporting wafer without binder in the channels (internal diameter, $4 \mathrm{~mm}$ ) of a stainless steel multisample holder. The sample holder was then placed in the centre of a quartz tube, which was equipped with gas and thermocouple ports and Kapton windows. The amount of sample used was optimized to achieve an XAS step height of about 0.5 . The XAS spectra were recorded in transmission mode.

The Pd fraction was calculated by conducting Pd XANES linear combination fittings using Athena in the IFEFFIT (version 1.2.11) package. XANES reference spectra were collected using a metallic Pd foil and a Pd oxide sample. Standard procedures based on WINXAS 3.1 software were used to fit the data in the extended X-ray abosrption fine structure regime. The extended X-ray abosrption fine structure coordination parameters were obtained by a least-square fit in $\mathrm{q}-$ and $r$-space of the isolated nearest neighbour, $k^{2}$-weighted Fourier transform data.

High-energy XRD. The cathode laminates after discharge were characterized by high-energy synchrotron XRD to determine the formation of $\mathrm{Li}_{2} \mathrm{O}_{2}$, which was carried out at the 11-ID-C beamline of the Advanced Photon Source, Argonne National Laboratory. The X-ray wavelength was $0.10804 \AA$. The samples were completely covered with Kapton tape as a protective film in the glove box to avoid any side reactions from the air. The XRD patterns were collected in the transmission mode using a Perkin Elmer large area detector. The collected twodimensional patterns were then integrated into conventional one-dimensional patterns (intensity versus $2 \theta$ ) for final data analysis using the Fit2d software.

X-ray photoelectron spectroscopy. Samples were analysed by XPS using a Kratos Axis Ultra DLD surface analysis instrument. The base pressure of the analysis chamber during these experiments was $3 \times 10^{-10}$ torr, with operating pressures around $1 \times 10^{-9}$ torr. Spectra were collected with a monochromatic Al K $\alpha$ source $(1486.7 \mathrm{eV})$ and a $300 \mu \times 700 \mu$ spot size. Before introduction into the load-lock vacuum chamber of the XPS instrument, all air-sensitive samples were loaded into an inert transfer module interfaced with the instrument. Samples were prepared in an Ar-filled glove box, with no more than 1 p.p.m. $\mathrm{O}_{2}$ and 1 p.p.m. $\mathrm{H}_{2} \mathrm{O}$. Nonconductive samples showed evidence of differential charging, resulting in peak shifts and broadening. Photoelectron peak positions were shifted back towards their true values and their peak widths were minimized by flooding the samples with low-energy electrons and ions from the charge neutralizer system on the instrument. Peak position correction was further corrected by referencing the $\mathrm{C} 1 \mathrm{~s}$ peak position of adventitious carbon for a sample $(284.8 \mathrm{eV}$, PHI Handbook of Photoelectron Spectroscopy) and shifting all other peaks in the spectrum accordingly. Fitting was done using the program CasaXPS. Peaks were fit as asymmetric Gaussian/Lorentzians, with $0-30 \%$ Lorentzian character. The FWHM of all subpeaks was constrained to $0.7-2.0 \mathrm{eV}$, as dictated by instrumental parameters, lifetime broadening factors and broadening due to sample charging. With this native resolution set, peaks were added and the best fit, using a least-squares fitting routine, was obtained while adhering to the constraints mentioned above.

Electron microscopy. A field-emission transmission electron microscope with a spherical and chromatic aberration imaging corrector working at $80 \mathrm{kV}$ was employed to evaluate the morphology and particle size of the ALD Pd catalysts, 
$\mathrm{Al}_{2} \mathrm{O}_{3}$ and $\mathrm{Li}_{2} \mathrm{O}_{2}$ toroids. Operation at $80 \mathrm{kV}$ was used to avoid knockout damage to carbon materials from the electron beam. Spherical and chromatic aberration correction enables the microscope to attain resolution better than $0.1 \mathrm{~nm}$ (measured by Young's fringes) at $80 \mathrm{kV}$. To prepare the TEM specimens, holey carbon grids were placed in the bottle of as-received powders and shaken to allow small powders to attach on the holey carbon. No liquid was used to avoid possible morphology change owing to the interaction with solution.

Theoretical calculations. All the density functional theory simulations (that is, geometry optimizations and energy calculations) were carried out based on plane wave basis functions. All the calculations were spin-polarized and carried out using the gradient-corrected exchange-correlation functional of Perdew, Burke and Ernzerhof. For the amorphous graphitized carbon slab (with total 264 atom), the initial amorphous geometry was obtained from classical many-body molecular dynamic simulation followed by full geometry relaxation using density functional theory. The oxidized palladium nanoparticle was represented by a $\mathrm{Pd}_{55} \mathrm{O}_{21}$ cluster with $\sim 1 \mathrm{~nm}$ particle size and cuboctahedron shape with the oxygen atoms occupying the hcp hollow positions of the available palladium (111) facets. The stacked two-layer graphene consists of 256 carbon atoms (with the bottom layer kept fixed during relaxation). For the amorphous $\mathrm{Li}_{2} \mathrm{O}_{2}$ bulk structure used to model the grain boundaries, the optimized geometry was obtained by randomly placing 54 $\mathrm{Li}_{2} \mathrm{O}_{2}$ molecules inside a cubic simulation cell $(12 \AA \times 12 \AA \times 12 \AA)$ after simulated annealing and lattice cell relaxation. More details can be found in Supplementary Methods.

\section{References}

1. Girishkumar, G., McCloskey, B., Luntz, A. C., Swanson, S. \& Wilcke, W Lithium air battery: promise and challenges. J. Phys. Chem. Lett. 1, 2193-2203 (2010).

2. Bruce, P. G., Freunberger, S. A., Hardwick, L. J. \& Tarascon, J.-M. Li- $\mathrm{O}_{2}$ and Li-S batteries with high energy storage. Nat. Mater. 11, 19-29 (2011).

3. Shao, Y. et al. Electrocatalysts for nonaqueous lithium-air batteries: status, challenges, and perspective. ACS Catal. 2, 844-857 (2012).

4. Christensen, J. et al. A critical review of li/air batteries. J. Electrochem. Soc. 159, R1-R30 (2011).

5. Abraham, K. M. \& Jiang, Z. A polymer electrolyte-based rechargeable lithium/ oxygen battery. J. Electrochem. Soc. 143, 1-5 (1996).

6. Yang, J. et al. Evidence for lithium superoxide-like species in the discharge product of a Li-O, battery. Phys. Chem. Chem. Phys 15, 3764-3771 (2013).

7. Oh, S. H. \& Nazar, L. F. Oxide catalysts for rechargeable high-capacity $\mathrm{Li}-\mathrm{O}_{2}$ batteries. Adv. Energy Mater. 2, 903-910 (2012).

8. Zhang, Z. et al. Increased stability toward oxygen reduction products for lithium-air batteries with oligoether-functionalized silane electrolytes. J. Phys. Chem. C 115, 25535-25542 (2011).

9. Peng, Z., Freunberger, S. A., Chen, Y. \& Bruce, P. G. A reversible and higherrate $\mathrm{Li}-\mathrm{O}_{2}$ battery. Science 337, 563-566 (2012).

10. Dathar, G. K. P., Shelton, W. A. \& Xu, Y. Trends in the catalytic activity of transition metals for the oxygen reduction reaction by lithium. J. Phys. Chem. Lett. 3, 891-895 (2012).

11. Qin, Y. et al. In situ fabrication of porous-carbon-supported $\alpha-\mathrm{MnO}_{2}$ nanorods at room temperature: application for rechargeable $\mathrm{Li}-\mathrm{O}_{2}$ batteries. Energy Environ. Sci. 6, 519-531 (2013).

12. Debart, A. 1., Bao, J., Armstrong, G. \& Bruce, P. G. An $\mathrm{O}_{2}$ cathode for rechargeable lithium batteries: the effect of a catalyst. J. Power Sour 174, 1177-1182 (2007)

13. Debart, A., Paterson, A. J., Bao, J. \& Bruce, P. G. Alpha- $\mathrm{MnO}_{2}$ nanowires: a catalyst for the $\mathrm{O}_{2}$ electrode in rechargeable lithium batteries. Angew. Chem. Int. Ed. 47, 4521-4524 (2008).

14. Lu, Y.-C. et al. Platinum gold nanoparticles: a highly active bifunctional electrocatalyst for rechargeable lithium air batteries. J. Am. Chem. Soc. 132, 12170-12171 (2010)

15. Trahey, L. et al. Synthesis, characterization, and structural modeling of highcapacity, dual functioning $\mathrm{MnO} 2$ electrode/electrocatalysts for $\mathrm{Li}^{-} \mathrm{O}_{2}$ cells. $A d v$. Energy Mater. 3, 75-84 (2013)

16. Freunberger, S. A. et al. Reactions in the rechargeable lithium- $\mathrm{O}_{2}$ battery with alkyl carbonate electrolytes. J. Am. Chem. Soc. 133, 8040-8047 (2011).

17. Mizuno, F., Nakanishi, S., Kotani, Y., Yokoishi, S. \& Iba, H. Rechargaeable Liair batteries with carbonate-based liquid electrolytes. Electrochemistry 78, 403-405 (2010).

18. Black, R. et al. Screening for superoxide reactivity in $\mathrm{Li}-\mathrm{O}_{2}$ batteries: effect on $\mathrm{Li}_{2} \mathrm{O}_{2} / \mathrm{LiOH}$ crystallization. J. Am. Chem. Soc 134, 2902-2905 (2012).

19. McCloskey, B. D. et al. On the efficacy of electrocatalysis in nonaqueous lithium- $\mathrm{O}_{2}$ batteries. J. Am. Chem. Soc. 133, 18038-18041 (2011).

20. Black, R., Lee, J.-H., Adams, B., Mims, C. A. \& Nazar, L. F. The role of catalysts and peroxide oxidation in lithium-oxygen batteries. Angew. Chem. Int. Ed. 125, 410-414 (2013)
21. Radin, M. D., Rodriguez, J. F., Tian, F. \& Siegel, D. J. Lithium peroxide surfaces are metallic, while lithium oxide surfaces are not. J. Am. Chem. Soc. 134, 1093-1103 (2012).

22. Viswanathan, V. et al. Electrical conductivity in $\mathrm{Li}_{2} \mathrm{O}_{2}$ and its role in determining capacity limitations in non-aqueous $\mathrm{Li}-\mathrm{O}(2)$ batteries. J. Chem Phys. 135, 214704-214714 (2011).

23. Ong, S. P., Mo, Y. \& Ceder, G. Low hole polaron migration barrier in lithium peroxide. Phys. Rev. B 85, 081105 (2012).

24. McCloskey, B. D. et al. Twin problems of interfacial carbonate formation in nonaqueous $\mathrm{Li}^{-} \mathrm{O}_{2}$ batteries. J. Phys. Chem. Lett. 3, 997-1001 (2012).

25. Ottakam Thotiyl, M. M., Freunberger, S. A., Peng, Z. \& Bruce, P. G. The carbon electrode in nonaqueous $\mathrm{Li}_{-} \mathrm{O}_{2}$ cells. J. Am. Chem. Soc. 135, 494-500 (2013).

26. Hummelshoj, J. S., Luntz, A. C. \& Norskov, J. K. Theoretical evidence for low kinetic overpotentials in $\mathrm{Li}^{-} \mathrm{O}_{2}$ electrochemistry. J. Chem. Phys. 138, 034703-034712 (2013)

27. Miikkulainen, V., Leskela, M., Ritala, M. \& Puurunen, R. L. Crystallinity of inorganic films grown by atomic layer deposition: overview and general trends. J. Appl. Phys. 113, 021301-021101 (2013).

28. Elam, J. W., Routkevitch, D., Mardilovich, P. P. \& George, S. M. Conformal coating on ultrahigh-aspect-ratio nanopores of anodic alumina by atomic layer deposition. Chem. Mater. 15, 3507-3517 (2003).

29. Shin, H., Jeong, D. K., Lee, J., Sung, M. M. \& Kim, J. Formation of $\mathrm{TiO}_{2}$ and $\mathrm{ZrO} 2$ nanotubes using atomic layer deposition with ultraprecise control of the wall thickness. Adv. Mater. 16, 1197-1200 (2004)

30. Chen, P. et al. Atomic layer deposition to fine-tune the surface properties and diameters of fabricated nanopores. Nano. Lett. 4, 1333-1337 (2004).

31. Feng, H., Libera, J. A., Stair, P. C., Miller, J. T. \& Elam, J. W. Subnanometer palladium particles synthesized by atomic layer deposition. ACS Catal. 1, 665-673 (2011).

32. Lu, J. \& Stair, P. C. Low-temperature ABC-type atomic layer deposition: synthesis of highly uniform ultrafine supported metal nanoparticles. Angew. Chem. Int. Ed. 49, 2547-2551 (2010).

33. Christensen, S. T. et al. Controlled growth of platinum nanoparticles on strontium titanate nanocubes by atomic layer deposition. Small 5, 750-757 (2009).

34. Feng, H., Elam, J. W., Libera, J. A., Setthapun, W. \& Stair, P. C. Palladium catalysts synthesized by atomic layer deposition for methanol decomposition. Chem. Mater. 22, 3133-3142 (2010).

35. Wang, X., Tabakman, S. M. \& Dai, H. Atomic layer deposition of metal oxides on pristine and functionalized graphene. J. Am. Chem. Soc. 130, 8152-8153 (2008).

36. Xuan, Y. et al. Atomic-layer-deposited nanostructures for graphene-based nanoelectronics. Appl. Phys. Lett. 92, 013101-013103 (2008).

37. Gong, B. \& Parsons, G. N. Quantitative in situ infrared analysis of reactions between trimethylaluminum and polymers during $\mathrm{Al}_{2} \mathrm{O}_{3}$ atomic layer deposition. J. Mat. Chem. 22, 15672-15682 (2012).

38. Assary, R. S. et al. The effect of oxygen crossover on the anode of a $\mathrm{Li}-\mathrm{O}_{2}$ battery using an ether-based solvent: insights from experimental and computational studies. ChemSusChem 6, 51-55 (2013).

39. Mitchell, R. R., Gallant, B. M., Thompson, C. V. \& Shao-Horn, Y. All-carbonnanofiber electrodes for high-energy rechargeable $\mathrm{Li}^{-} \mathrm{O}_{2}$ batteries. Energy Environ. Sci. 4, 2952-2958 (2011).

40. Lu, Y. et al. Room temperature methane detection using palladium loaded single-walled carbon nanotube sensors. Chem. Phys. Lett. 391, 344-348 (2004).

41. Assary, R. S., Lau, K. C., Amine, K., Sun, S.-K. \& Curtiss, L. A. Interactions of dimethoxy ethane with $\mathrm{Li}_{2} \mathrm{O}_{2}$ clusters and likely decomposition mechanisms for Li- $\mathrm{O}_{2}$ batteries. J. Phys. Chem. C 117, 8041-8090 (2013).

\section{Acknowledgements}

This work was supported by the U.S. Department of Energy under Contract DE-AC02 $06 \mathrm{CH} 11357$ with the main support provided by the Vehicle Technologies Office, Department of Energy (DOE) Office of Energy Efficiency and Renewable Energy (EERE). J.Lu was supported by the Department of Energy (DOE) Office of Energy Efficiency and Renewable Energy (EERE) Postdoctoral Research Award under the EERE Vehicles Technology Program administered by the Oak Ridge Institute for Science and Education (ORISE) for the DOE. This work was also partially supported from the Tailored Interfaces for Energy Storage, an Energy Frontier Research Center, Office of Basic Energy Sciences Research. This work was also supported by the Human Resources Development of the Korea Institute of Energy Technology Evaluation and Planning (KETEP) grant funded by the Korean government, Ministry of Knowledge and Economy (No. 20114010203150) and by the National Research Foundation of Korea (NRF) grant funded by the Korea government (MEST; No. 2009-0092780). We acknowledge grants of computer time through INCITE and ALCC awards for BlueGene/P computer at Argonne National Laboratory and allocations on the CNM Carbon Cluster at Argonne National Laboratory, the ALCF Fusion Cluster at Argonne National Laboratory, and the EMSL Chinook Cluster at Pacific Northwest National Laboratory. Use of the Advanced Photon Source and the Electron Microscopy Center at Argonne National Laboratory was 
supported by the U.S. Department of Energy, Office of Basic Energy Sciences, under contract No. DE-AC02-06CH11357.

\section{Author contributions}

J.L. and K.A. designed the experiments; Y.L. and J.W.E. synthesized the cathode materials. D.J.M., J.W. and J.L. performed and analysed the imaging experiments; J.L. and X.L. performed and analysed the X-ray measurements; J.L., P.D. and X.L. tested the cathode materials; and K.C.L., U.D., R.S.A. and L.A.C. were responsible for the theoretical computations. Y.K.S., L.A.C. and K.A. supervised the project; L.A.C., J.L. and K.A. wrote the paper. All of the authors discussed the results and reviewed the manuscript.

\section{Additional information}

Supplementary Information accompanies this paper at http://www.nature.com/ naturecommunications

Competing financial interests: The authors declare no competing financial interests.

Reprints and permission information is available online at http://npg.nature.com/ reprintsandpermissions/

How to cite this article: Lu, J. et al. A nanostructured cathode architecture for low charge overpotential in lithium-oxygen batteries. Nat. Commun. 4:2383 doi: $10.1038 /$ ncomms3383 (2013). 


\section{Corrigendum: A nanostructured cathode architecture for low charge overpotential in lithium-oxygen batteries}

Jun Lu, Yu Lei, Kah Chun Lau, Xiangyi Luo, Peng Du, Jianguo Wen, Rajeev S. Assary, Ujjal Das, Dean Miller, Jeffrey W. Elam, Hassan M. Albishri, D Abd El-Hady, Yang-Kook Sun, Larry A. Curtiss \& Khalil Amine

Nature Communications 4:2383 doi: 10.1038/ncomms3383 (2013); Published 29 Aug 2013; Updated 19 Feb 2014

The main SEM image in Fig. 4c of this Article was inadvertently duplicated from panel e. The correct version of Fig. 4 appears below.
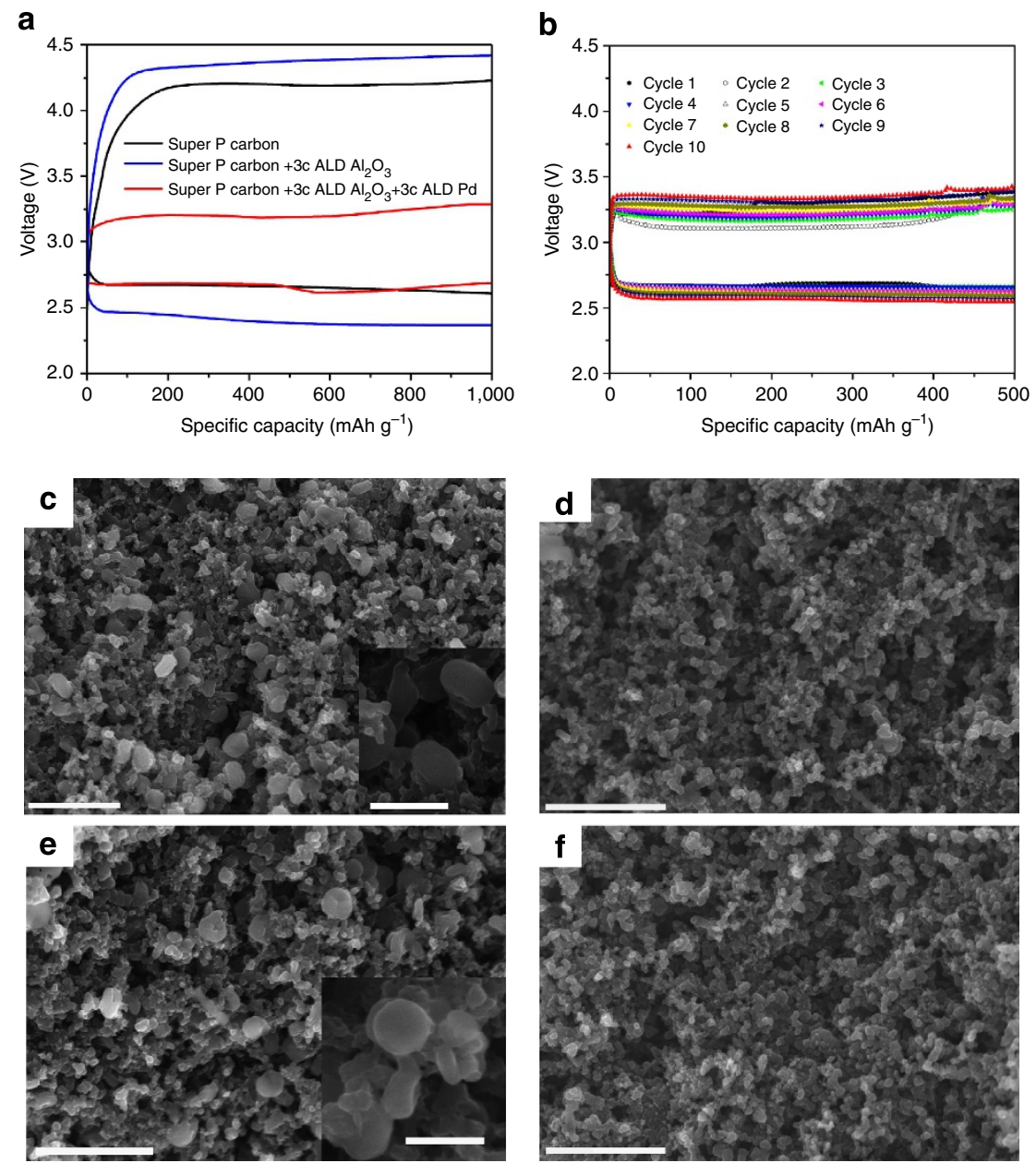